\title{
RURAL WOMEN PERCEPTION ON BUSHMEAT TRADE AROUND KAINJI LAKE NATIONAL PARK, NIGER STATE, NIGERIA
}

Adefalu, L.L., ${ }^{1}$ Oladipo, F.O., ${ }^{1}$ *Usman, B.A., ${ }^{2}$ Babalola, F.D., ${ }^{3}$ Amusa,T.0. ${ }^{3}$ and Egere, S. ${ }^{1}$

DOI: http://dx.doi.org/10.4314/ejesm.v5i1.3

Received $1^{\text {st }}$ December 2011: accepted 30th January 2012

\begin{abstract}
The study examines the perception of rural women on bushmeat trade around Kainji Lake National Park in Niger state, Nigeria. Multi-stage random sampling technique was used to select 120 rural women living around kainji lake national park in Niger state. Data were collected through a well-structured interview schedule and analyzed using frequency counts, percentages, 5 points Likert-type scale and chisquare. The result of the study revealed that majority (69.2\%) of the rural women were married with large household sizes, $70.3 \%$ were in their middle age and $67.1 \%$ had just basic education. Also, majority (95.0\%) of them had long years of working experience with low average monthly income less than US $\$ 61$. Moreover, they perceived benefits of trading in bush meat to include high return (1st), raising social status (2nd), and cheap access to animal protein (3rd). The study revealed further that respondents' perceived knowledge were very high (2.5-3.0) on hunting and trading of bushmeat as not being a good livelihood activity, high (1.9-2.4) on unregulated hunting and trading of wild species as a factor that can destroy the environment while other opinions such as eating any wild animal meat be it endangered or not, extinction of wild species not contributing to disequilibrium of biodiversity, etc were rated low (1.31.8). There were significant relationship between education and years of working experience with respondents' perception on bushmeat trade while age, household size, marital status and average monthly income were not significant. The perception exhibited by the rural women which was believed to be highly beneficial as a result of their generally low knowledge on the implication of the trade on biodiversity could encourage participation in bushmeat trade. Based on the findings, massive enlightenment campaigns need to be embarked upon by both governmental and non-governmental organizations to change their mindset on the implication of bushmeat trade.
\end{abstract}

Key Words: Perception, Bushmeat, Rural Women, Trade, National Park

\section{Introduction}

Bushmeat is one of the forest resources that are believed to be easily accessed by the resourcepoor rural dwellers. According to DEFRA (2006), bushmeat is defined as wild animal protein that is hunted for human consumption. Women's participation in this bushmeat trade appears to be greater than that of men and is believed to be a popular scenario in the rural communities of Nigeria. Rural women play prominent role in the trading of bushmeat and its products at village level and in supplying urban markets. People travel from far and nearby communities to buy fresh and smoked bushmeat on designated market days which varies from village to village. Rural women's children are found by the roadside, displaying bushmeat to the attention of the passersby who may be interested in buying the product. Some of these meat items are eventually

${ }^{1}$ Department of Agricultural Extension and Rural Development

University of Ilorin, Ilorin, Nigeria

${ }^{2}$ Department of Geography and Environmental Management

University of Ilorin, Ilorin, Nigeria

${ }^{3}$ Department of Forest Resources Management

University of Ilorin, Ilorin, Nigeria

*Corresponding Author email: bolicon2004@yahoo.co.uk taken into places like hotels, restaurants and homes, where they are served as special meat. In other to avoid detection, much of trade in bushmeat, take place early in the morning, at weekends and holidays when forestry officials are not on duty.

Bushmeat trade is attractive to poor-ruralhouseholds because it provides high returns to labour with low risk and minimal capital outlay. Bushmeat also serve as cheap protein source to the rural people who may not be able to afford meats from domestic animals (Branch, 2000). However, the situation is different in the urban areas where bushmeat command very high prices in the City Restaurants and is only an exclusive reserve for the highly privileged individuals who regard eating the meat as a way of linking up with their 
rural ancestors and an attribute of high degree of affluence.

Studies have found that income from bushmeat sales was particularly important for the poor rural households and was given higher priority by them than other livelihood activities (De Merode et al, 2004). Women have a prominent role in the trading of bushmeat commodities. The hunting of bushmeat is predominantly done by men who incidentally are husbands, fathers, brothers or children of the rural women. The processing, storage, trading and cooking of the meat is essentially carried out by women otherwise known as producers in isolated areas (Brown, 2003). Bushmeat serves as safetynet for the rural women in times of hardship when the resources can be relied upon for improved food security.

A prevailing characteristic of the trade is that it is generally informal and frequently illegal. This makes accurate estimates of the size and importance of the bushmeat trade difficult to accomplish. However some data are available for example from west and central Africa, which suggest that bushmeat is significant both in terms of trade and nutrition. Indeed, in Liberia Anstey (1991) estimated the bushmeat trade to be worth more than the timber trade. Other estimates of the bushmeat trade have been made for countries like Gabon put at US \$21 million in 1993 for rural areas and US\$26 million for urban areas (Steel 1994). In Liberia it was estimated to be US \$24 million in 1988 (Anstey, 1991). Ivory Coast: US\$117m (Bowen- Jones, 1998); Nigeria and Ghana: similar to Liberia (Fa and Purvis, 1997).

Bushmeat makes a considerable contribution to rural tropical forest economic livelihood and human nutrition. Due to its informal often illegal nature, the bush meat traders' contribution to these rural economic is hidden from official statistics. Bushmeat traders are important drivers of wild life hunting as they provide steady market for these all important products and may even have a number of local professional hunters who are paid in advance to supply them with bushmeat on a full time basis Fimbel et al, (2000).

In spite of the numerous benefits derivable from trade in bushmeat and its products by rural women, it is important to understand the danger inherent in having too much contact with these wild species. Women are particularly predisposed to zoonotic diseases due to their frequent involvement in cutting, processing and cooking of bushmeat. Leroy et al (2004) noted that contact with fresh meat during hunting and butchering, is a potential pathway for interspecies transmission of viruses. Besides, the steady market opportunity provided by rural women in the trade of bushmeat could drive even wild animals regarded as threatened species to the endangered status. This concern was supported by Fimbel et al (2000) in a study where they asserted that, in certain areas, these changes have even resulted in subsistence hunting becoming locally unsustainable.

In view of the foregoing challenges, this study intends to provide relevant answers to the following research questions:

- what are the socio-economic characteristics of rural women in the study area?

- what are the perceived benefits from bushmeat trade

- what are the perceived knowledge of rural women on endangered species of bushmeat?

\section{Objectives of the Study}

The general objective of this study is to assess the perceptions of rural women on bushmeat trade around Kainji Lake Park.

The specific objectives are to:

(i) describe the socio- economic characteristics of rural women living around Kainji lake National park.

(ii) identify the perceived benefits of rural women on bushmeat trade,

(iii) examine the perceived knowledge of rural women on endangered species of bushmeat trade

\section{Hypothesis of the Study}

$\mathrm{Ho}_{1}$ : There is no significant relationship between socio-economic characteristics of the rural women and their perceptions on endangered species of bushmeat trade

\section{Methodology \\ The Study Area}

The study was carried out in the rural communities around Kainji Lake national park of Niger state, Nigeria. The Park was established in 1976 and it is situated between latitude $9^{0} 40^{1}$ and $10^{\circ} 30^{1}$ and longitude $3^{0} 3^{1}$ and $5^{0} 50^{1} \mathrm{E}$ and has a total land mass of 5,370.82 km square. Kainji Lake national park comprises of different ethnic groups such as Hausa, Nupe and Gwari. The topography of the 
park is undulating with a general decrease in elevation from West to East. The vegetation of the park is typical of the Sudan-guinea savanna, although in some areas it appears more Sahelian, Riparian forest occur on the banks of the larger watercourses. Kainji Lake national park is made up of some villages among which are Wawa, Malale, Luma, Kali, Duruma Kemenji (Meduna et $a l, 2004)$.

The study population comprised of all rural women living in the communities around Kainji lake national park in Niger state, Nigeria. Multistage random sampling technique was used for the study. Firstly, four villages out of the thirteen major villages in the area were selected. The second stage involved random selection of two women associations from each of the selected villages and finally a random selection of fifteen respondents were made from each of the selected women associations, making a total sample size of one hundred and twenty. Data were collected using interview schedule which was personally conducted to elicit information from the respondents.

\section{Results and Discussion}

Table 1shows that majority $(70.3 \%)$ of the respondents were within the age bracket of less than 30 and 50years. This implies that majority of the respondents were still in their active age which may place them at advantage over the aged in shuttling around the village to make effective transactions. Also, majority $(69.2 \%)$ of the respondents was married and as such the extra marital responsibilities conferred on them may necessitate their participation in trades in order to meet up with family and other needs. About $38.8 \%$ of the respondents had secondary education, $27.5 \%$ had primary education $12.5 \%$ had both Arabic and Adult education, $8.3 \%$ had non-formal and the rest $(0.8 \%)$ had Tertiary education. This shows that most of the respondents were educated with the majority having basic education $(67.1 \%)$ though at lower level. The high literacy level among the respondents may enhance easy transmission and acceptance of awareness message on wildlife conservation. Table 1 also shows that above average $(54.2 \%)$ of the respondents indicated a large household size of 11 and above, $27.5 \%$ indicated a household size of 610 while the rest $(18.3 \%)$ had between 1 to 5 household size. The large household size of majority $(81.7 \%)$ may reduce the cost of labour required in trading activities.

Furthermore, it is shown in the table 1 that $45.0 \%$ of the respondents had working experience of $11-15$ years, $33.3 \%$ had 16 years or more experience, $16.7 \%$ had working experience ranging from 6-10 years while a few (5.0\%)of them had less or equal 5 years working experience. The reasonably long years of experience among majority $(95.0 \%)$ of the respondents shows that their perception on the endangered species of wild life could be reckoned with. The average monthly income of the respondents as depicted in table 1shows that majority $(65.8 \%)$ of the respondents' earnings range from less than N5000 and $\mathrm{N} 10.00,24.2 \%$ earned between $\mathrm{N} 10,001$ and $\mathrm{N} 15,000$ while the rest $8.3 \%$ and $1.7 \%$ of them earned over N15,000 and above N20,000 respectively.

According to table 2, trading in bush meat gives high return ranked $1^{\text {st }}$, participation in trading help to raise our social status ranked $2^{\text {nd }}$, trading guarantees cheap access to animal protein ranked $3^{\text {rd }}$ while proceeds from bushmeat trading is used to assist our husbands as perceived importance of bush meat trade and free access to metaphysical power were ranked least $\left(9^{\text {th }}\right)$. From this analysis, it could be deduced that respondents perceived the bush meat trade as being highly beneficial and may be adduced points of attraction to the trade.

Table 3 shows that respondents had very high knowledge (2.5-3.0) on hunting and trading of bushmeat as not being a good livelihood activity, high knowledge (1.9-2.4) on unregulated hunting and trading of wild species as a factor that can destroy the environment while the rest test perceived statements such as eating any wild animal meat be it endangered or not, extinction of wild species is not contributory to disequilibrium of biodiversity, wild species are natural creatures and inexhaustible, wild animals are special gifts from God, wild species cannot go into extinction and trade in bushmeat enhances reproductive rates of wild species were rated low (1.3-1.8).The implication of this result is that respondents have the tendency to participate in bushmeat trade considering their generally low level of knowledge (information) on the danger the trade constitutes to biodiversity. 


\section{Hypothesis Testing}

H1: There is no significant relationship between selected socio-economic characteristics of rural women and their perception on endangered species of bushmeat trade

$\begin{array}{lc}\text { Variable } & \text { df } \\ \text { Age } & 4 \\ \text { Education } & 5 \\ \text { Household size } & 2 \\ \text { Marital } & 4 \\ \text { Working experience } & 3 \\ \text { Average monthly income } & 4 \\ \text { Source: Field Survey (2011) }\end{array}$

Result of test of hypothesis on table 4 shows that, education and years of working experience of respondents were significantly related with their perception on bushmeat trade while age, household size, marital status and average monthly income were not significant. This implies that education and years of working experience are contributory factors to adequate knowledge about the dangers inherent in bushmeat trade.

\section{Conclusion and Recommendations}

The study found that majority of the respondents were in their active age, married with large household sizes and had long years of working (bushmeat trade) experience. Also, most of them were educated though at low or basic level (primary and secondary education) and generally low income earners with majority $(65.8 \%)$ of the respondents earning below ten thousand and one naira $(\mathrm{N} 10,001.00)$. It was found that the respondents' perception on bushmeat trade which was believed to be highly beneficial as a result of their generally low knowledge could encourage more women participation in the trade and portends a great danger on the biodiversity of the Kainji Lake National Park. However, given the result of test of hypothesis, education and years of working experience of respondents were found to be contributory factors to adequate knowledge about the dangers inherent in bushmeat trade.

Based on the findings, massive enlightenment campaign need to be embarked upon by both governmental and non-governmental organizations to change their mindset on the implication of bushmeat trade on certain species of wild animals (threatened and endangered
Table 4: Chi-square distribution of significant relationship between selected socio-economic characteristics of rural women and their perception on endangered species of bushmeat trade.
$\mathbf{X}^{2}$ Cal

17.80

$\mathbf{X}^{\mathbf{2}}$ Table Value
9.49
11.07
5.99
9.49
7.81
9.49

Decision

Not significant
Significant
Not significant
Not significant
Significant
Not significant

species).Coupled with this, law enforcement agency, in this regard, Forestry department, needs to intensify efforts in curbing the menace of trade in threatened and endangered species.

\section{References}

Anstey, S. (1991), Wildlife Utilization in Liberia. WWF/FDA Wildlife Survey Report.

Brown, D. (2003), Bushmeat and Poverty Alleviation: Implications for Development

Policy. Wildlife Policy Briefings. Overseas Development Institute, London.

Available

http://www.odi.org.uk/freq/publications/policy-

briefs/wildlifepolicy/2.htm/.

Bowen-Jones, E. (1998), A review of the Commercial Bushmeat trade with emphasis on

Central West Africa and the Great Apes. The Apes Alliance.

DEFRA (2006), Webpage: Facts about Bushmeat (Department of Environment, Food and

Rural Affairs).

Available

http://www.defra.gov.uk/animalh/illegali/tropics/b ushmeat.htm

Fa, J.E. and Purvis, A. (1997), Body size, diet and population density in Afrotropical

Forest Mammals: A comparison with Neotropical species. Journal of Animal Ecology 66, 98-112

Fimbel, C; Curran, B. and Usongo, L. (2000), Enhancing the sustainability of duiker hunting through community participation and controlled access in the Lobeke region of South Easthern Cameroon. In Hunting for sustainability in Tropical Forests. (eds) Robinson, J.G and Bennett, E.L. pp. 356-374. Columbia University Press, New York. 
Leroy, E.M., Rouquet, P., Formenty, P., Souquie` re, S.,Kilbourne, A., Froment, J.-M., Bermejo, M., Smit, S.,Karesh, W., Swanepoel, R., Zaki, S.R. Rollin,P.E. (2004), Multiple Ebola virus transmission events and rapid decline of Central African Wildlife. Science 303, 387-390.

Table 1: Socio- Economic Characteristics of Rural Women

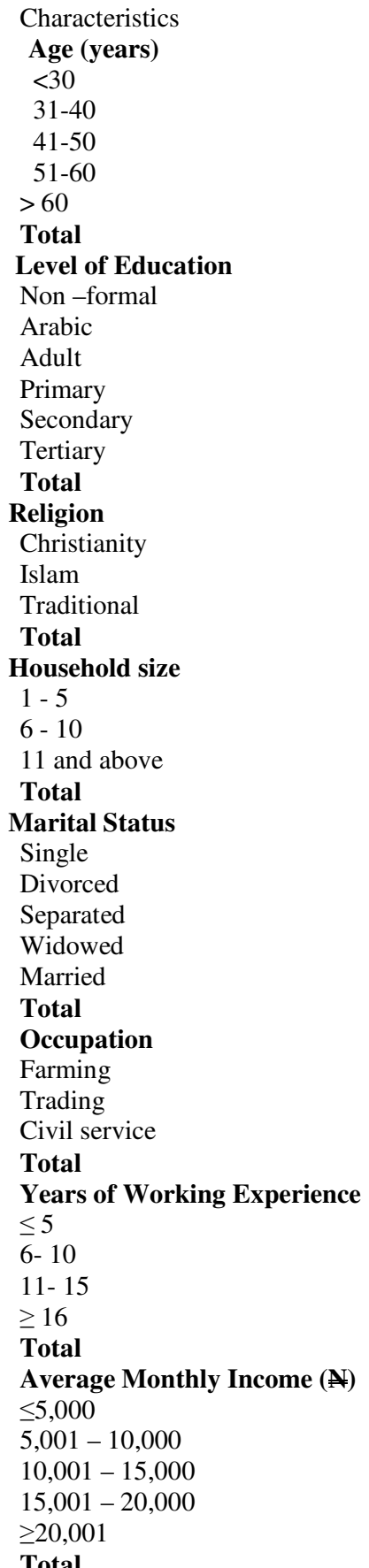

Meduna, A.J.; Ogunjinmi, A.A. and Onadeko, S.A. (2009). Biodiversity Conservation

Problems and their implications on Ecotourism in Kanji Lake National Park, Nigeria. Journal of Sustainable Development in Africa, 10(4), 15201550

Percentage (\%)
5.8
22.8
41.7
29.2
0.8
$\mathbf{1 0 0}$

8.3

12.5

12.5

27.5

38.8

0.8

100

56.7

42.5

0.8

100

18.3

27.5

54.2

100

8.3

7.5

0.8

14.2

69.2

100

75.0

16.7

8.3

100

5

16.7

45

33.3

100

33.3

32.5

24.2

8.3

1.7

100 
Table 2 Distribution of respondents on the basis of perceived benefits from bushmeat Trade

\begin{tabular}{|c|c|c|c|c|c|c|c|}
\hline Benefits from trade & SA & A & $\mathrm{D}$ & SD & NS & Mean & Rank \\
\hline Trading in bush meat gives high return & $70(58.3)$ & $\begin{array}{l}50 \\
(41.7)\end{array}$ & $0(0.0)$ & $0(0.0)$ & $0(0.0)$ & 4.58 & $1^{\text {st }}$ \\
\hline $\begin{array}{l}\text { Participation in trading help to raise our social } \\
\text { status }\end{array}$ & $21(17.5)$ & $\begin{array}{l}32 \\
(26.7)\end{array}$ & $\begin{array}{l}40 \\
(33.3)\end{array}$ & $\begin{array}{l}24 \\
(20.0)\end{array}$ & $3(2.5)$ & 3.37 & 2nd \\
\hline Free access to metaphysical power & $0(0.0)$ & $2(1.7)$ & $7(5.8)$ & $\begin{array}{l}68 \\
(50.7)\end{array}$ & $\begin{array}{l}43 \\
(35.8)\end{array}$ & 1.73 & 9th \\
\hline $\begin{array}{l}\text { Proceeds from bushmeat trading is used to } \\
\text { assist our husbands }\end{array}$ & $0(0.0)$ & $0(0.0)$ & $\begin{array}{l}20 \\
(16.7)\end{array}$ & $\begin{array}{l}48 \\
(40.0)\end{array}$ & $\begin{array}{l}52 \\
(43.3)\end{array}$ & 1.73 & $9^{\text {th }}$ \\
\hline $\begin{array}{l}\text { Trading guarantees cheap access to animal } \\
\text { protein }\end{array}$ & $25(20.8)$ & $\begin{array}{l}48 \\
(40.0)\end{array}$ & $\begin{array}{l}18 \\
(15.0)\end{array}$ & $\begin{array}{l}20 \\
(16.5)\end{array}$ & $9(7.5)$ & 3.50 & $3^{\text {rd }}$ \\
\hline It gives sense of belongingness to traders & $0(0.0)$ & $4(3.3)$ & $8(6.7)$ & $\begin{array}{l}89 \\
(74.2)\end{array}$ & $\begin{array}{l}19 \\
(15.8)\end{array}$ & 1.95 & $6^{\text {th }}$ \\
\hline $\begin{array}{l}\text { It helps to sustain leadership positions in the } \\
\text { bushmeat traders association }\end{array}$ & $0(0.0)$ & $8(6.7)$ & $2(1.7)$ & $\begin{array}{l}62 \\
(51.7)\end{array}$ & $\begin{array}{l}48 \\
(40.0)\end{array}$ & 1.75 & $8^{\text {th }}$ \\
\hline Continuity of family tradition & $0(0.0)$ & $0(0.0)$ & $\begin{array}{l}40 \\
(33.3)\end{array}$ & $\begin{array}{l}20 \\
(16.7)\end{array}$ & $\begin{array}{l}60 \\
(50.0)\end{array}$ & 1.83 & $7^{\text {th }}$ \\
\hline $\begin{array}{l}\text { Income from trade is used to pay children } \\
\text { school fees }\end{array}$ & $0(0.0)$ & $\begin{array}{l}32 \\
(26.7)\end{array}$ & $\begin{array}{l}76 \\
(63.3)\end{array}$ & $\begin{array}{l}12 \\
(10.0)\end{array}$ & $0(0.0)$ & 3.16 & $4^{\text {th }}$ \\
\hline Access to wide variety of animal meat & $32(26.7)$ & $\begin{array}{l}24 \\
(20.0)\end{array}$ & $\begin{array}{l}52 \\
(43.3)\end{array}$ & $\begin{array}{l}12 \\
(10.0)\end{array}$ & $0(0.0)$ & 2.00 & $5^{\text {th }}$ \\
\hline
\end{tabular}

Source: Field Survey (2011)

Table 3 Perceived knowledge of rural women on Endangered Species of Bushmeat trade

\begin{tabular}{|l|l|l|l|l|l|l|l|l|}
\hline Perception & SA & A & D & SD & NS & Mean & SD & Remark \\
\hline $\begin{array}{l}\text { We eat any wild animal meat (endangered } \\
\text { or not) }\end{array}$ & $\begin{array}{l}52 \\
(43.4)\end{array}$ & $\begin{array}{l}30 \\
(25.7)\end{array}$ & $\begin{array}{l}16 \\
(13.3)\end{array}$ & $\begin{array}{l}20 \\
(16.7)\end{array}$ & $2(1.6)$ & 1.4 & 0.70 & Low \\
\hline $\begin{array}{l}\text { Extinction of wild species cannot lead to } \\
\text { disequilibrium in eco-system }\end{array}$ & $\begin{array}{l}58 \\
(48.3)\end{array}$ & $\begin{array}{l}36 \\
(30.0)\end{array}$ & $\begin{array}{l}20 \\
(16.7)\end{array}$ & $6(5.0)$ & $0(0.0)$ & 1.5 & 0.80 & Low \\
\hline $\begin{array}{l}\text { Wild species are inexhaustible in the } \\
\text { forest }\end{array}$ & $\begin{array}{l}19 \\
(15.8)\end{array}$ & $\begin{array}{l}56 \\
(46.7)\end{array}$ & $\begin{array}{l}24 \\
(20.0)\end{array}$ & $\begin{array}{l}18 \\
(15.0)\end{array}$ & $3(2.5)$ & 1.7 & 1.00 & Low \\
\hline Wild animals are special gifts from God & $9(7.5)$ & $\begin{array}{l}30 \\
(25.0)\end{array}$ & $\begin{array}{l}39 \\
(32.5)\end{array}$ & $\begin{array}{l}36 \\
(30.0)\end{array}$ & $6(5.0)$ & 1.8 & 0.72 & Low \\
\hline Wild species can never go into extinction & $\begin{array}{l}24 \\
(20.0)\end{array}$ & $\begin{array}{l}60 \\
(50.0)\end{array}$ & $\begin{array}{l}30 \\
(25.0)\end{array}$ & $6(5.0)$ & $0(0.0)$ & 1.8 & 0.76 & Low \\
\hline $\begin{array}{l}\text { Trade in bushmeat enhances the } \\
\text { replacement (reproductive) rate of the } \\
\text { wild species in the forest }\end{array}$ & $\begin{array}{l}48 \\
(40.0)\end{array}$ & $\begin{array}{l}33 \\
(27.5)\end{array}$ & $\begin{array}{l}18 \\
(15.0)\end{array}$ & $\begin{array}{l}15 \\
(12.5)\end{array}$ & $6(5.0)$ & 1.6 & 1.12 & Low \\
\hline $\begin{array}{l}\text { Unregulated hunting and trading of wild } \\
\text { species can destroy the environment }\end{array}$ & $\begin{array}{l}18 \\
(15.0)\end{array}$ & $\begin{array}{l}72 \\
(60.0)\end{array}$ & $\begin{array}{l}12 \\
(10.0)\end{array}$ & $\begin{array}{l}10 \\
(8.3)\end{array}$ & $8(6.7)$ & 2.2 & 0.83 & High \\
\hline $\begin{array}{l}\text { Hunting and trading of bushmeat is not a } \\
\text { good livelihood activity }\end{array}$ & $\begin{array}{l}76 \\
(63.3)\end{array}$ & $\begin{array}{l}30(5.0) \\
(25.0)\end{array}$ & $8(6.7)$ & $0(0.0)$ & 2.8 & 0.81 & $\begin{array}{l}\text { Very } \\
\text { high }\end{array}$ \\
\hline
\end{tabular}

NB: always=3; Sometimes $=2$; Never $=1$; Not sure $=0$ (Highest possible score $=3.0$ ). Very low $=0.7-1.2$;

Low $=1.3-1.8 ;$ High $=1.9-2.4 ;$ Very high $=2.5-3.0$.

Source: Field Survey (2011) 